\title{
SOIL FERTILITY AND PRODUCTIVITY OF SUGARCANE INFLUENCED BY ENRICHED PRESSMUD COMPOST WITH CHEMICAL FERTILIZERS
}

\author{
S. M. Bokhtiar ${ }^{* 1}$, S. Roksana ${ }^{2}$ and A. Z. M. Moslehuddin ${ }^{2}$ \\ Bangladesh Sugarcrop Research Institute, Ishurdi, Pabna, Bangladesh
}

\begin{abstract}
A field experiment was conducted at Bangladesh Sugarcrop Research Institute, Ishurdi, Pabna, Bangladesh to examine the effects of enriched compost with chemical fertilizers on soil fertility and productivity of sugarcane. The experiment was laid out in Randomized Complete Block Design (RCBD) with 16 treatments comprising four levels of inorganic fertilizers $(100 \%, 75 \%, 50 \%$ and $0 \%$ ) and four levels of pressmud (enriched by Trichoderma harzianum @ $7.5 \mathrm{t} \mathrm{ha}^{-1}$, T. viride@ $7.5 \mathrm{t} \mathrm{ha}^{-1}$, untreated raw pressmud @ $10 \mathrm{t} \mathrm{ha}^{-1}$ and control). It was observed that germination (90.34\%), total chlorophyll content $\left(2.58 \mathrm{mg} \mathrm{g}^{-1}\right)$, leaf area index (5.00), dry matter $\left(3.41 \mathrm{~kg} \mathrm{~m}^{-2}\right)$, tiller $\left(137.94 \times 000 \mathrm{ha}^{-1}\right)$, millable cane stalk $\left(99.15 \times 000 \mathrm{ha}^{-1}\right)$ and yield $\left(111.32 \mathrm{t} \mathrm{ha}^{-1}\right)$ were found maximum in $100 \%$ recommended fertilizer $\left(\mathrm{N}_{150} \mathrm{P}_{50} \mathrm{~K}_{90} \mathrm{~S}_{35}\right.$ and $\mathrm{Zn}_{4} \mathrm{~kg}$ $\mathrm{ha}^{-1}$ ) with enriched pressmud which was statistically identical in comparison with $75 \%$ and $50 \%$ of recommended chemical fertilizers with enriched pressmud. The N (1.47\%), K (1.24\%) and S $(0.17 \%)$ contents of leaf tissues were slightly increased with chemical fertilizers + enriched pressmud compared to chemical fertilizer alone. Soil Organic C, total N, $\mathrm{P}, \mathrm{K}$ and $\mathrm{S}$ were higher with pressmud application compared to non pressmud application. Microbial enrichment of pressmud with Trichoderma sp. could save $2.5 \mathrm{t} \mathrm{ha}^{-1}$ of pressmud and $25 \%$ of recommended fertilizers. It can be concluded that enriched pressmud is more effective than raw pressmud in increasing sugarcane yield and maintain soil fertility in High Ganges River Floodplain soils.
\end{abstract}

Keywords: Enriched pressmud, Trichoderma sp., fertility, productivity,

sugarcane

\footnotetext{
* Corresponding author email: bokhtiarsm@yahoo.com

${ }^{1}$ Natural Resources Management Division, Bangladesh Agricultural Research Council, Dhaka 1215

${ }^{2}$ Soil Science Department, Bangladesh Agricultural University, Mymensingh- 2202, Bangladesh
}

Received: 28.09.2015 


\section{INTRODUCTION}

In Bangladesh, sugarcane (Saccharum officinarum L.) is cultivated in 0.12 million hectares with an average cane yield of $41 \mathrm{t} \mathrm{ha}^{-1}$ (BBS, 2011). The productivity is much lower compared to average productivity of world $71.5 \mathrm{t} \mathrm{ha}^{-1}$ (FAOSTAT, 2009). Despite a favourable land, soil type and agro-climatic condition, per hectare yield of sugarcrop in Bangladesh is very low. This low yield and recovery of sugar is mainly due to management factors at the production level. Most soils in Bangladesh are low in organic matter $(\mathrm{OM})$ generally containing $1.5 \% \mathrm{OM}$, while 2.5 to $3.0 \% \mathrm{OM}$ is necessary for sustainable crop production. Because of its large biomass yield and long growth period, sugarcane requires a considerable amount of plant nutrients for its vegetative growth and development. Due to significant depletion of soil nutrients, sugarcane soils become less fertile and fail to produce higher yield. Hence, nutrient replenishment through the addition of fertilizer and manures in the soil is indispensable for achieving sustainable cane production. Results indicate addition of organic matter increases organic carbon, aggregate stability, moisture retention capacity and infiltration rate of the surface soil while reducing bulk density (Sarker et al., 2003). This valuable component of soils in Bangladesh is likely to be declined with time due to poor attention for its improvement and maintenance.

Integrated use of chemical and organic fertilizers are found to be more beneficial for sustainable sugarcane production. The combined use of organic and inorganic fertilizer gave significantly higher sugarcane yield and economic benefit (Paul et al., 2007). Pressmud is one such source of organic matter produced as industrial waste which can be profitably utilized for sugarcane production. Pressmud is a good source of organic matter, NPK and important micronutrients and has established its importance in improving fertility, productivity and other physical properties of agricultural soils (Rangaraj et al., 2007; Kumar and Verma, 2002). Moisture content of fresh pressmud is around $60 \%$ and oven dried pressmud contained $20 \%$ Organic C, $2.35 \%$ total $\mathrm{N}, 0.13 \%$ available $\mathrm{P}, 0.54 \%$ exchangeable $\mathrm{K}$, $0.56 \%$ available $\mathrm{S}, 6.64 \% \mathrm{Ca}, 0.46 \% \mathrm{Mg}, 128 \mathrm{ppm} \mathrm{Cu}, 6300$ ppm Fe, 308 ppm Mn and $883 \mathrm{ppm} \mathrm{Zn}$ (Bokhtiar and Sakurai, 2007). Like other organic manures, pressmud has great potential to supply nutrients in addition to its favorable effects on physicochemical and biological properties of soil. Bokhtiar et al., 2007 observed 25\% reduction of fertilizer application was possible with the use of FYM or pressmud @ $15 \mathrm{t} \mathrm{ha}^{-1 .}$ The production of pressmud amounts to about 3 percent of cane crashed in the sugar factory. Being an excellent source of nutrients adds organic matter; pressmud addition leads to better nitrogen nutrition and promotes cation exchange capacity. By virtue of the chemical composition and high content of organic carbon, the usefulness of pressmud as a valuable organic manure has been reported by several workers (Nehra and Hooda, 2002; Jamil et al., 2008; Ramaswamy, 1999). However, these studies did not include enriched pressmud combined with chemical fertilizers. Hence, a study was conducted to evaluate pressmud enrichment with Trichoderma 
sp. and chemical fertilizers on sugarcane for improving the soil fertility and productivity.

\section{MATERIALS AND METHODS}

\section{Experimental site and soil characteristics}

The experiment was conducted at the experimental farm of the Bangladesh Sugarcrop Research Institute, Ishurdi, Pabna during January 2011 to January 2012. The experimental site represents the High Ganges River Flood Plain soils under the Agro-ecological Zone 11. The soil belongs to Sara series. The soil was loamy in texture having $\mathrm{pH} 7.62$, organic $\mathrm{C} 0.46 \%$, total $\mathrm{N} 0.060 \%$, available phosphorus $15.0 \mathrm{ppm}$, exchangeable potassium $0.18 \mathrm{meq} / 100 \mathrm{~g}$ soil, available sulphur $24.0 \mathrm{ppm}$ and available zinc $0.64 \mathrm{ppm}$.

\section{Treatments and experimental design}

Sixteen treatments having Four levels of inorganic fertilizers $(100 \%, 75 \%$, $50 \%$ and $0 \%$ of recommended fertilizer dose) and four levels of pressmud enrichment (Trichoderma harzianum @ $7.5 \mathrm{t} \mathrm{ha}^{-1}$,T.viride@ $7.5 \mathrm{t} \mathrm{ha}^{-1}$, untreated raw pressmud @ $10 \mathrm{t} \mathrm{ha}^{-1}$ and no pressmud) were laid out in Randomized Complete Block Design (RCBD) with three replications. The treatment details are given in table 1 . The unit plotsize was $6 \mathrm{~m} \times 6 \mathrm{~m}$. Recommended rates of inorganic fertilizers (urea, triple super phosphate, muriate of potash, gypsum and zinc sulphate) and pressmud were used. Two microorganisms (Trichoderma harzianum and Trichoderma viride) were used for enrichment of pressmud.

\section{Preparation of enriched pressmud}

Pressmud was composted by spreading in layers of $15 \mathrm{~cm}$ thickness inter mixed with microbial inoculants Trichoderma harzianum and T. viride. One litre of Trichoderma bio-agent was mixed with 20 litre of water for making 2 tons of pressmud. The material was heaped to a height of 3 feet and pulverized at an interval of 15 days. The entire lot was left for 40 days for decomposition. Sufficient moisture level was maintained by periodically sprinkling water over the heap. Untreated heap served as control. After 40 days, the samples were collected for analysis. 
Table 1. Details of treatments evaluated on sugarcane

\begin{tabular}{|c|c|c|}
\hline Treatments & Inorganic source & Organic source pressmud \\
\hline $\mathrm{T}_{1}: \mathrm{RFD}+$ Pm.Th7.5 & $\begin{array}{l}\text { 150-50-90-34-3.5 NPKSZn kg ha } \\
\text { (100\% recommended fertilizer) }\end{array}$ & $\begin{array}{l}\text { Enriched Pressmud by } \\
\text { Trichoderma harzianum } 7.5 \mathrm{t} \text { ha } \\
1\end{array}$ \\
\hline $\mathrm{T}_{2}: \mathrm{RFD}+$ Pm.Tv7.5 & 150-50-90-34-3.5 NPKS kg ha-1 & $\begin{array}{l}\text { Enriched Pressmud by } \\
\text { Trichoderma viride } 7.5 \mathrm{t} \mathrm{ha}^{-1}\end{array}$ \\
\hline $\mathrm{T}_{3}: \mathrm{RFD}+$ Pm.R10 & 150-50-90-34-3.5 NPKS kg ha ${ }^{-1}$ & Raw pressmud $10 \mathrm{t} \mathrm{ha}^{-1}$ \\
\hline $\mathrm{T}_{4}: \mathrm{RFD}$ & 150-50-90-34-3.5 NPKS kg ha ${ }^{-1}$ & 0 \\
\hline $\begin{array}{l}\mathrm{T}_{5}: 0.75 \mathrm{RFD}+ \\
\mathrm{Pm} . \mathrm{Th} 7.5\end{array}$ & $\begin{array}{l}\text { 112-37-68-26-2.6 NPKS kg ha } \\
\text { (75\% recommended fertilizer) }\end{array}$ & $\begin{array}{l}\text { Enriched Pressmud by } \\
\text { Trichoderma harzianum } 7.5 \mathrm{t} \text { ha } \\
1\end{array}$ \\
\hline $\begin{array}{l}\mathrm{T}_{6}: 0.75 \mathrm{RFD}+ \\
\text { Pm.Tv7.5 }\end{array}$ & 112-37-68-26-2.6 NPKS kg ha ${ }^{-1}$ & $\begin{array}{l}\text { Enriched Pressmud by } \\
\text { Trichoderma viride } 7.5 \mathrm{t} \mathrm{ha}^{-1}\end{array}$ \\
\hline $\begin{array}{l}\mathrm{T}_{7}: 0.75 \mathrm{RFD}+ \\
\text { Pm.R10 }\end{array}$ & 112-37-68-26-2.6 NPKS kg ha ${ }^{-1}$ & Raw pressmud $10 \mathrm{t} \mathrm{ha}^{-1}$ \\
\hline $\mathrm{T}_{8}: 0.75 \mathrm{RFD}$ & 112-37-68-26-2.6 NPKS kg ha ${ }^{-1}$ & 0 \\
\hline $\begin{array}{l}\mathrm{T}_{9}: 0.5 \mathrm{RFD}+ \\
\text { Pm. Th7.5 }\end{array}$ & $\begin{array}{l}\text { 75-25-45-17-1.8 NPKSZn kg ha-1 } \\
\text { (50\% recommended fertilizer) }\end{array}$ & $\begin{array}{l}\text { Enriched Pressmud by } \\
\text { Trichoderma harzianum } 7.5 \mathrm{t} \text { ha } \\
1\end{array}$ \\
\hline $\begin{array}{l}\mathrm{T}_{10}: 0.5 \mathrm{RFD}+ \\
\text { Pm.Tv7.5 }\end{array}$ & 75-25-45-17-1.8 NPKSZn kg ha-1 & $\begin{array}{l}\text { Enriched Pressmud by } \\
\text { Trichoderma viride } 7.5 \mathrm{t} \mathrm{ha}^{-1}\end{array}$ \\
\hline $\mathrm{T}_{11}: 0.5 \mathrm{RFD}+\mathrm{Pm} \cdot \mathrm{R} 10$ & 75-25-45-17-1.8 NPKSZn kg ha & Raw pressmud $10 \mathrm{t} \mathrm{ha}^{-1}$ \\
\hline $\mathrm{T}_{12}: 0.5 \mathrm{RFD}$ & 75-25-45-17-1.8 NPKSZn kg ha-1 & 0 \\
\hline $\begin{array}{l}\mathrm{T}_{13}: 0.0 \mathrm{RFD}+ \\
\text { Pm.Th7.5 }\end{array}$ & 0 & $\begin{array}{l}\text { Enriched Pressmud by } \\
\text { Trichoderma harzianum } 7.5 \mathrm{t} \text { ha } \\
1\end{array}$ \\
\hline $\begin{array}{l}\mathrm{T}_{14}: 0.0 \mathrm{RFD}+ \\
\text { Pm.Tv7.5 }\end{array}$ & 0 & $\begin{array}{l}\text { Enriched Pressmud by } \\
\text { Trichoderma viride } 7.5 \mathrm{t} \mathrm{ha}^{-1}\end{array}$ \\
\hline $\mathrm{T}_{15}: 0.0 \mathrm{RFD}+\mathrm{Pm} . \mathrm{R} 10$ & 0 & Raw pressmud $10 \mathrm{t} \mathrm{ha}^{-1}$ \\
\hline $\mathrm{T}_{16}: 0.0 \mathrm{RFD}+$ Pm.0.0 & 0 & 0 \\
\hline
\end{tabular}

Notes: RFD = Recommended Fertilizer dose for sugarcane (150-50-90-34-3.5 NPKSZn kg ha ${ }^{-1}$ ); Pm.Th7.5 = Enriched Pressmud by Trichoderma harzianum $7.5 \mathrm{t} \mathrm{ha}^{-1}$; Pm.Tv7.5= Enriched Pressmud by Trichoderma viride $7.5 \mathrm{t} \mathrm{ha}^{-1}$; Pm.R10 = Raw Pressmud $10 \mathrm{t} \mathrm{ha}^{-1}$. 


\section{Fertilizer application}

Treatment wise fertilizers were applied as per recommended urea, triple supper phosphate, muriate of potash, gypsum and zinc sulphate @ 150, 50, 90, 34 and $3.4 \mathrm{~kg} \mathrm{ha}^{-1}$, respectively. Full dose of triple supper phosphate, gypsum, zinc sulphate and ${ }^{1} / 3$ rd of muriate of potash and urea were applied in trenches and mixed with soil prior to planting of setts as basal. The rest amount of urea and muriate of potash were applied as top dressing in two equal splits at 120 and 180 days after planting (DAP). After each application, fertilizers were incorporated into the soil by spade. Full amount of pressmud was applied in furrows during final land preparation before sett placement

\section{Planting technique, cultural practices and data collection}

Following conventional method, three budded setts (variety Isd 37) were planted end to end in furrows. Each plot contains six lines of $6.0 \mathrm{~m}$ long. Twenty six setts were placed in each line. Prior to planting regent 3GR was applied in the trenches @ $33 \mathrm{~kg} \mathrm{ha}^{-1}$ to control termite and Furadan 5G was applied as a preventive measure against borers in two times at 90 and 150 DAP at $40 \mathrm{~kg} \mathrm{ha}^{-1}$ for each time. Apart from chemical, cultural and mechanical control measures were done for insect-pests and disease management as and when required. In the main field, flood irrigation was given in trenches just after planting of the setts. Also supplementary irrigation was done during the dry period depending on the crop growth and whenever required. The soil in the trenches was loosened twice at 30 and 60 DAP to free the plants from soil compaction. All the plots were kept weed free up to 140 days after plantation, as the period is considered to be the critical period for crop-weed competition for sugarcane. Earthing-up around cane plant and propping of sugarcane were done at 150 days after planting to protect the cane stalks from lodging against the possibility of strong wind.

\section{Soil and plant analyses}

Soil textural class was determined by hydrometer method and soil $\mathrm{pH}$ was measured in a 1:2.5 soil water suspension by glass electrode $\mathrm{pH}$ meter. Total $\mathrm{N}$ was determined by macro Kjeldahl procedure and organic carbon by the Walkley and Black method. Available soil $\mathrm{P}$ was extracted with $0.5 \mathrm{M}$ NaHCO3 and the amount was determined by spectrophotometry. Exchangeable K (1N NH4OAc extractable) was determined by flame photometry and available $\mathrm{S}$ by turbidimetric method (Black, 1965) for soil and plant leaf. Elements like $\mathrm{Ca}, \mathrm{Mg}, \mathrm{Cu}, \mathrm{Zn}, \mathrm{Mn}$ and Fe were performed using an atomic absorption spectrometry (Shimadzu AA-6300) following Petersen (2002). The chlorophyll contents of cane leaf were determined at grand growth phase i.e., 220 DAP. Midribs were removed from the leaf blade. For extraction in $80 \%$ ethanol, small pieces of green leaves were stored in darkness at room temperature and humidity until extracts were completed. All extracts were assayed for absorbance at 663 and $645 \mathrm{~nm}$ to measure chlorophyll a (Chl a) and chlorophyll $\mathrm{b}(\mathrm{Chl} \mathrm{b})$ content $\left(\mathrm{mg} \mathrm{g}^{-1}\right.$ fresh weight) respectively after using the 
formula of Arnon (1949). Leaf area index and total dry matter production were calculated following the method given by Shimabuku et al. (1980). Sugarcane was harvested at maturity stage after 12 month of planting.

\section{Statistical analysis}

The collected data were statistically analyzed using the "Analysis of variance" (ANOVA) technique and the significance of mean differences were adjusted by the Duncan's New Multiple Range Test (DMRT) (Gomez and Gomez, 1984) with the help of MSTAT-C programme.

\section{RESULTS AND DISCUSSION}

\section{Nutrient composition of enriched and raw pressmud}

Enriched pressmud after 40 days of Trichoderma sp. incorporation and raw pressmud were analyzed for different nutritional status and the data is presented in table 2. Enrichment of pressmud by microorganisms exerted beneficial effect for some elements. The amount of nitrogen, phosphorus, potassium and sulphur were higher in T. harzianum enriched pressmud than T. viride enriched pressmud or raw pressmud. However phosphorus, potassium and sulphur contents were higher in $T$. viride enriched pressmud than raw pressmud. The organic matter content and other elements were almost same as raw pressmud or enriched pressmud by Trichoderma $s p$.

\section{Germination and yield parameters of sugarcane}

There was significant effect of the different treatments on germination percentage of sugarcane (Table 3). However, the variation among the treatments was not wide. The treatment $\mathrm{T}_{1}$ with enriched pressmud by Trichoderma harzianum @ $7.5 \mathrm{t} \mathrm{ha}^{-1}$ along with $100 \%$ recommended fertilizer (RFD) produced the highest germination of sugarcane $(90.34 \%)$ which was statistically similar with $\mathrm{T}_{2}$ to $\mathrm{T}_{11}$ except $\mathrm{T}_{8}$. The lowest germination $(68.05 \%)$ was recorded in $T_{15}$ treatment which was statistically on par with $T_{1}$ and $T_{7}$. There was significant difference in tillering of sugarcane at 150 days after planting due to different treatments (Table 3). The treatment $\mathrm{T}_{1}$ having enriched pressmud by Trichoderma harzianum @ $7.5 \mathrm{t} \mathrm{ha}^{-1}$ plus 100\% RFD produced significantly higher number of tillers $\left(139.10 \times 10^{3} \mathrm{ha}^{-1}\right)$ and it was statistically on par with $\mathrm{T}_{2}$ to $\mathrm{T}_{11}$ except $\mathrm{T}_{8}$, and $\mathrm{T}_{14}$. The $\mathrm{T}_{16}$ (control) produced significantly lower number of tillers $\left(102.9 \times 10^{3} \mathrm{ha}^{-1}\right)$ than any other treatments. However, it was statistically similar to $\mathrm{T}_{12}, \mathrm{~T}_{13}$ and $\mathrm{T}_{15}$. The application of enriched pressmud by two microorganisms along with inorganic fertilizer had some beneficial effects on cane length and the effect was also statistically significant. The treatment $\mathrm{T}_{2}$ with enriched pressmud by $T$. viride at $7.5 \mathrm{t} \mathrm{ha}^{-1}$ plus $100 \%$ RFD produced the tallest cane $(3.897 \mathrm{~m})$. The treatment $\mathrm{T}_{15}$ produced the lowest cane length which was statistically on par with other treatments except $\mathrm{T}_{2}, \mathrm{~T}_{9}$ and $\mathrm{T}_{10}$. Results of different treatments on cane girth was significant but 
variation was not much. The cane girth varied from $1.80 \mathrm{~cm}$ in $\mathrm{T}_{16}$ treatment to 2.08 $\mathrm{cm}$ in $\mathrm{T}_{9}$ treatment. The treatment $\mathrm{T}_{9}$ produced the highest cane girth $(2.08 \mathrm{~cm})$ was statistically onpar to all other treatments. The findings confirms with the results of Shahid et al. (2011). There was no significant effect of different treatments on millable cane production of sugarcane.

\section{Cane yield}

There was a significant effect of different treatments of using chemical fertilizer and pressmud on sugarcane yield (Table 3 ). The cane yield ranged from $59.06 \mathrm{t} \mathrm{ha}^{-1}$ in $\mathrm{T}_{16}$ (control) to $111.9 \mathrm{t} \mathrm{ha}^{-1}$ in $\mathrm{T}_{3}$ treatment. The treatment $\mathrm{T}_{3}$ having raw pressmud $10 \mathrm{t} \mathrm{ha}^{-1}$ plus $100 \%$ RFD produced the highest cane yield which was statistically on par with $\mathrm{T}_{1}, \mathrm{~T}_{2}, \mathrm{~T}_{6}$ and $\mathrm{T}_{12}$. Application of $100 \%$ RFD alone $\left(\mathrm{T}_{4}\right)$ gave less cane yield than $100 \%$ RFD with enriched pressmud by microorganisms or raw pressmud ( $T_{1}$ to $T_{3}$ which were statistically similar to each other). The $\mathrm{T}_{3}$ treatment having 100\% RFD plus raw pressmud @ $10 \mathrm{t} \mathrm{ha}^{-1}$ produced higher but statistically similar yield with $\mathrm{T}_{1}$ and $\mathrm{T}_{2}$ where enriched pressmud @ $7.5 \mathrm{t}$ $\mathrm{ha}^{-1}$ with same amount of inorganic fertilizer was used. Thus it is clear that, with enrichment of pressmud by using Trichoderma sp. use of pressmud could be reduced by $2.5 \mathrm{t} \mathrm{ha}^{-1}$ in sugarcane. The increased amount of $\mathrm{N}, \mathrm{P}, \mathrm{K}$ and $\mathrm{S}$ contents in enriched pressmud could be the reason behind the need of its less amount over raw pressmud. Again, $75 \%$ RFD plus enriched pressmud by $T$. viride $\left(\mathrm{T}_{6}\right)$ produced higher cane yields $\left(100.7\right.$ tha $\left.^{-1}\right)$ than with the pressmud enriched by $T$. harzianum or with raw pressmud $\left(\mathrm{T}_{5}\right.$ and $\mathrm{T}_{7}: 97.67$ and $97.39 \mathrm{t} \mathrm{ha}^{-1}$, respectively) or even $75 \%$ RFD alone $\left(T_{8}\right)$ without any pressmud. Although, all cane yields from $T_{5}$ to $T_{8}$ were statistically similar to each other, the value of $T_{6}$ was similar to the $T_{1}$ to $T_{3}$, where $100 \%$ RFD was used with pressmud. Thus, it could save $25 \%$ of inorganic fertilizer. The result obtained with the $\mathrm{T}_{12}$, seems to be unusually high, which might be contributed by a higher level of soil fertility of the soil. Again, pressmud enriched with T. harzianum @ $7.5 \mathrm{t} \mathrm{ha}^{-1}$ without any chemical fertilizer $\left(\mathrm{T}_{13}\right)$ produced higher yield than enriched pressmud by $T$. viride $\left(\mathrm{T}_{14}\right)$ or raw pressmud $\left(\mathrm{T}_{15}\right)$. Shankaraiah and Murthy (2005) also observed similar findings and reported that the addition of enriched pressmud cake @10 t ha ${ }^{-1}$ saved fertilizer NPK by 50\% which was comparable with raw pressmud at $15 \mathrm{t} \mathrm{ha}^{-1}$. However, it is clear that the combined application of enriched pressmud or raw pressmud with chemical fertilizers improved the cane yield and the effect was more pronounced at higher fertilizer level $(100 \%$ RFD). Application of enriched pressmud or raw pressmud with 50\% RFD or $75 \%$ RFD recorded yields at par with $100 \%$ RFD as chemical fertilizers alone, respectively. The present findings corroborates with findings of Rakkiyappan et al. (2001).

\section{Total chlorophyll content, dry matter and leaf area index}

There was a significant effect of different treatments of using chemical fertilizer and pressmud on chlorophyll content (Table 4). The chlorophyll content 
ranged from $1.66 \mathrm{mg} \mathrm{g}^{-1}$ in $\mathrm{T}_{5}$ to $2.58 \mathrm{mg} \mathrm{g}^{-1}$ in $\mathrm{T}_{2} . \mathrm{T}_{2}$ having enriched pressmud by Trichoderma viride @7.5 $\mathrm{t} \mathrm{ha}^{-1}$ plus 100\% RFD produced the highest chlorophyll content in leaf and was statistically identical to those found in all treatments except $\mathrm{T}_{5}, \mathrm{~T}_{7}$ and $\mathrm{T}_{11}$.

There was significant difference in dry matter of sugarcane due to application of inorganic fertilizer and pressmud (raw or enriched with microorganism) in different combinations. The treatment $\mathrm{T}_{7}$ having raw pressmud plus $75 \%$ RFD produced significantly the highest dry matter content $\left(3.71 \mathrm{~kg} \mathrm{~m}^{-2}\right)$ and statistically similar with all other treatments except $\mathrm{T}_{13}-\mathrm{T}_{16}$. The $\mathrm{T}_{16}$ (control) treatment produced significantly lowest dry matter $\left(1.94 \mathrm{~kg} \mathrm{~m}^{-2}\right)$ than any other treatments. Application of $100 \%$ RFD plus enriched pressmud by $T$. harzianum produced less dry matter than $100 \%$ RFD plus enriched pressmud by $T$. viride @ $7.5 \mathrm{t} \mathrm{ha}^{-1}$ or with raw pressmud or alone but all four were statistically similar. Similarly $75 \%$ inorganic fertilizer plus raw pressmud produced higher dry matter $\left(3.71 \mathrm{~kg} \mathrm{~m}^{-2}\right)$ than any other treatments. When $50 \%$ inorganic fertilizer was applied alone or with enriched pressmud by $T$. harzianum, it produced less dry matter than the same amount of inorganic fertilizer was used with raw pressmud or enriched pressmud by $T$. viride treatments $\left(\mathrm{T}_{10}\right.$ to $\left.\mathrm{T}_{11}\right)$ and all those produced statistically identical yield to each other. There was significant effect of enriched pressmud by microorganisms in leaf area index of sugarcane but the variation was not wide (Table 4 ). The treatment $\mathrm{T}_{7}$ having raw pressmud plus $75 \%$ RFD produced significantly higher leaf area index but statistically similar with all other treatments except $\mathrm{T}_{14}$ and $\mathrm{T}_{16}$. The $\mathrm{T}_{16}$ (control) treatment produced significantly lowest leaf area index (2.89) than any other treatments. Application of $100 \%$ RFD plus raw pressmud produced less leaf area index (LAI) than $100 \%$ recommended fertilizer plus enriched pressmud by microorganisms or alone but all four treatments were statistically similar. Again, $75 \%$ inorganic fertilizer plus raw pressmud produced higher leaf area (5.28) than any other treatments. $75 \%$ inorganic fertilizer plus enriched pressmud by Trichoderma viride $7.5 \mathrm{t} \mathrm{ha}^{-1}$ produced second highest Leaf area index than any other treatments. When 50\% inorganic fertilizer was applied with raw pressmud produced better leaf area than other treatment $\left(\mathrm{T}_{9}, \mathrm{~T}_{10}\right.$ and $\mathrm{T}_{12}$ ) those produced statistically identical leaf area index to each other. Bokhtiar et al. (2005) found similar results and reported that application of organic manure along with chemical fertilizer increased leaf area index (LAI), total dry matter (TDM), chlorophyll contents.

\section{Leaf nutrient content at 150 DAP}

The integrated use of pressmud in combination with inorganic fertilizer remarkably increased Ncontent in leaf of sugarcane at 150 days after planting (Table 5). The highest $\mathrm{N}$ content was recorded in $\mathrm{T}_{6}$ followed by Trichoderma viride mixed pressmud along with inorganic fertilizer. But the use of pressmud alone or with inorganic fertilizer showed no significant effect on $\mathrm{P}$ content in sugarcane leaf. The integrated application of micro-organism mixed pressmud with inorganic fertilizer 
produced higher $\mathrm{K}$ content in leaf. The use of pressmud along with inorganic fertilizer showed higher $\mathrm{S}$ content and comparatively better Zncontent in leaves of sugarcane. Bokhtiar et al. (2001) obtained similar results from their studies.

\section{Soil fertility}

Use of micro-organism mixed pressmud alone or in combination with inorganic fertilizer remarkably increased soil carbon, total $\mathrm{N}$, available $\mathrm{P}, \mathrm{S}$ and $\mathrm{Zn}$ and exchangeable $\mathrm{K}$ (Table 6). The results in the present study revealed that organic carbon, total $\mathrm{N}$, available $\mathrm{P}$, exchangeable $\mathrm{K}$, available $\mathrm{S}$ and $\mathrm{Zn}$ were built up in soils with microorganism mixed pressmud combined with inorganic fertilizers in sugarcane compared to control plots. The findings were in line with the results obtained by Venkatakrishnan et al. (2007).

\section{CONCLUSION}

It was observed that soil organic $\mathrm{C}$, total $\mathrm{N}, \mathrm{P}, \mathrm{K}$ and $\mathrm{S}$ were higher with pressmud application compared to non pressmud application. Microbial enrichment of pressmud with Trichoderma sp. could save $2.5 \mathrm{t} \mathrm{ha}^{-1}$ of pressmud and $25 \%$ of recommended fertilizers. It can be concluded that enriched pressmud is more effective than raw pressmud in increasing sugarcane yield and maintain soil fertility in High Ganges River Floodplain soils.

\section{ACKNOWLEDGEMENT}

The author is pleased to extend gratefulness to the Ministry of Science and Information \& Communication Technology, Government of the People's Republic of Bangladesh for financial support for the research work.

\section{REFERENCES}

Arnon, D. I. 1949. Copper enzymes in isolated chloroplast polyphenoloxidase in Beta vulgaris. Plant Physiology, 24: 1-15

BBS, Bangladesh Bureau of Statistics. 2011. Yearbook of Agricultural Statistics of Bangladesh. Bangladesh Bureau of Statistics. Statistics and Informatics Division, Ministry of Planning. Government of the peoples' Republic of Bangladesh. pp.112

Black, C. A. 1965. Methods of soil analysis. Part 2: Chemical and microbiological properties. Agronomy series No.9, Madison Wisconsin, USA. American Society of Agronomy and American Society for Testing and Materials

Bokhtiar, S. M. and Sakurai, K. 2007. Effects of integrated nutrient management on plant crop and successive first and second ratoon crops of sugarcane in Bangladesh. Journal of Plant Nutrition, 30: 135-147

Bokhtiar, S. M. and Sakurai, K. 2005. Integrated use of organic manure and chemical fertilizer on growth, yield, and quality of sugarcane in High Ganges River Floodplain soils of Bangladesh. Communications in Soil Science and Plant Analysis, 36(13/14): 1823-1837 
Bokhtiar, S. M., Islam, M. J. and Chowdhury, S. N. A. 2000. Effect of pressmud along with inorganic fertilizers on sugarcane yield and fertility status of soil. Bangladesh Journal of Training and Development, 13(1/2): 175-180

Bokhtiar, S. M., Paul, G. C., Rashid, M. A. and Rahman, A. B. M. M. 2001. Effect of press mud and inorganic fertilizer on soil fertility and yield of sugarcane grown in High Ganges River Floodplain soils of Bangladesh. Indian Sugar, LI (IV): 235-241

FAOSTAT. 2009. Food and Agricultural Organization of the United Nations: Economic and Social Department: The Statistical Division. pp.567

Gomez, K. A. and Gomez, A. A. 1984. Statistical Procedure for Agricultural Research. John Willey and Sons. New York, Brisbane. Singapore. pp. 139-240

Jamil, M., Qasim, M. and Zia, M. S. 2008. Utilization of pressmud as organic amendment to improve physic-chemical characteristics of calcareous soil under two legume crops. Journal of the Chemical Society of Pakistan, 30(4): 577-582

Kumar, V. and Verma, S. K. 2002. Influence of use of organic manure in combination with inorganic fertilizers on sugarcane and soil fertility. Indian Sugar, 52(3): 177-181

Paul, G. C., Bokhtiar, S. M., Rashed, M. A. and Mannan, M. A. 2007. Integrated nutrient management for sustainable sugarcane production in different agro-ecological zones of Bangladesh. Planter, 83(977): 529-538

Petersen, L. 2002. Analytical method: Soil, water, plant material, fertilizer. Soil Resource Management and Analytical Services. Soil Resource Development Institute, Dhaka. Bangladesh

Rakkiyappan, P., Thangavelu, S., Malathi, R. and Radhamani, R. 2001. Effect of biocompost and enriched pressmud on sugarcane yield and quality. Sugar Technology, 3(3): 92-96

Ramaswamy, P. P.1999. Recycling of agricultural and agro-industry waste for sustainable agricultural production. Journal of the Indian Society of Soil Science, 47 (4): 661-665

Rangaraj, T., Somasundaram, E. M., Amanullah, M., Thirumurugan, V. Ramesh, S. and Ravi, S. 2007. Effect of agro-industrial wastes on soil properties and yield of irrigated finger miller (Eleusine coracana L. Gaertn) in coastal soil. Research Journal of Agriculture and Biological Sciences, 3(3): 153-156

Sarkar, S., Singh, S. R. and Singh, R. P.2003. The effect of organic and inorganic fertilizers on soil physical condition and the productivity of a rice-lentil cropping sequence in India. The Journal of Agricultural Science, 140: 419-425

Shahid, Z., Ahmed, A. U. and Javeed, H. M. R. 2011. Integrated application of fertilizers and biocane (organic fertilizers) to enhance the productivity and juice quality of autumn planted sugarcane (Saccharum officinarum L.). African Journal of Agricultural Research, 6(21): 4857-4861

Shankaraiah, C. and Murthy, K. N. K. 2005. Effect of enriched pressmud cake on growth, yield and quality of sugarcane. Sugar Technology, 7(2/3): 1-4

Shimabuku, M., Kudo, M. and Miyagi, Y. 1980. Study on the dry matter production of sugarcane. Part.1.Character of dry matter production in the process of growth in autumn planting of sugarcane. Bulletin of the Okinawa Agricultural Experiment Station, 5:1-15

Venkatakrishnan, D. and Ravichandran, M. 2007. Influence of nutrient management on growth and yield of sugarcane. Plant Archives, 7(1): 99-102 
Table 2. Composition of different nutrients of raw pressmud and enriched pressmud

\begin{tabular}{|c|c|c|c|}
\hline $\begin{array}{c}\text { Elements } \\
(\%)\end{array}$ & Raw pressmud & $\begin{array}{c}\text { Enriched pressmud } \\
\text { by Trichoderma } \\
\text { harzianum }\end{array}$ & $\begin{array}{c}\text { Enriched pressmud } \\
\text { by } \\
\text { T. viride }\end{array}$ \\
\hline Moisture & 23.43 & 29.30 & 29.13 \\
\hline Organic matter & 39.59 & 38.90 & 39.59 \\
\hline $\mathrm{N}$ & 2.95 & 3.28 & 2.81 \\
\hline $\mathrm{P}$ & 0.31 & 0.46 & 0.38 \\
\hline $\mathrm{K}$ & 0.54 & 0.58 & 0.56 \\
\hline $\mathrm{S}$ & 0.59 & 0.75 & 0.72 \\
\hline $\mathrm{Zn}$ & 0.016 & 0.016 & 0.015 \\
\hline $\mathrm{Fe}$ & 0.15 & 0.15 & 0.15 \\
\hline $\mathrm{Mn}$ & 0.04 & 0.04 & 5.61 \\
\hline $\mathrm{Ca}$ & 5.52 & 5.66 & 0.236 \\
\hline $\mathrm{Mg}$ & 0.235 & 0.235 & 0.010 \\
\hline $\mathrm{Cu}$ & 0.011 & 0.011 & 0.0006 \\
\hline $\mathrm{Ni}$ & 0.0006 & 0.0007 & 0.0002 \\
\hline $\mathrm{Cd}$ & 0.00014 & 0.00014 & 0.002 \\
\hline $\mathrm{Pb}$ & 0.002 & 0.002 & \\
\hline
\end{tabular}


Table 3. Effect of different treatments on cane germination, tiller production, length, girth and millable cane

\begin{tabular}{|c|c|c|c|c|c|c|}
\hline Treatments & $\begin{array}{c}\text { Germination } \\
(\%)\end{array}$ & $\begin{array}{l}\text { Tiller at } 150 \\
\text { DAP } \\
\left(\times 10^{3} \mathrm{ha}^{-1}\right)\end{array}$ & $\begin{array}{l}\text { Cane } \\
\text { length } \\
(\mathrm{m})\end{array}$ & $\begin{array}{c}\text { Cane } \\
\text { girth }(\mathrm{cm})\end{array}$ & $\begin{array}{c}\text { Number of } \\
\text { millable } \\
\text { cane } \\
\left(\times 10^{3} \mathrm{ha}^{-1}\right)\end{array}$ & $\begin{array}{c}\text { Cane } \\
\text { yield } \\
\left(\mathrm{t} \mathrm{ha}^{-1}\right)\end{array}$ \\
\hline $\mathrm{T}_{1}: \mathrm{RFD}+\mathrm{Pm} . \mathrm{Th} 7.5$ & 90.34 & 139.1 & 3.60 & 1.98 & 96.38 & 107.80 \\
\hline $\mathrm{T}_{2}: \mathrm{RFD}+\mathrm{Pm} . \mathrm{Tv} 7.5$ & 75.85 & 135.3 & 3.90 & 1.95 & 99.15 & 102.70 \\
\hline $\mathrm{T}_{3}: \mathrm{RFD}+\mathrm{Pm} \cdot \mathrm{R} 10$ & 79.49 & 137.9 & 3.56 & 1.95 & 99.15 & 111.90 \\
\hline $\mathrm{T}_{4}: \mathrm{RFD}$ & 77.18 & 128.3 & 3.51 & 1.93 & 96.48 & 93.86 \\
\hline $\begin{array}{ccc}\mathrm{T}_{5}: & \begin{array}{c}0.75 \mathrm{RFD} \\
\text { Pm.Th7.5 }\end{array}\end{array}+$ & 78.37 & 126.5 & 3.45 & 1.89 & 93.62 & 97.67 \\
\hline $\mathrm{T}_{6}: 0.75 \mathrm{RFD}+$ Pm.Tv7.5 & 79.43 & 127.0 & 3.59 & 1.90 & 94.09 & 100.07 \\
\hline $\mathrm{T}_{7}: 0.75 \mathrm{RFD}+\mathrm{Pm} \cdot \mathrm{R} 10$ & 87.50 & 125.9 & 3.58 & 1.96 & 95.81 & 97.39 \\
\hline $\mathrm{T}_{8}: 0.75 \mathrm{RFD}$ & 72.35 & 119.6 & 3.59 & 1.93 & 92.38 & 91.94 \\
\hline $\mathrm{T}_{9}: 0.5 \mathrm{RFD}+$ Pm.Th7.5 & 77.71 & 137.9 & 3.69 & 2.08 & 88.95 & 85.68 \\
\hline $\mathrm{T}_{10}: 0.5 \mathrm{RFD}+\mathrm{Pm} . \mathrm{Tv} 7.5$ & 77.64 & 128.3 & 3.71 & 1.96 & 98.29 & 95.18 \\
\hline $\mathrm{T}_{11}: 0.5 \mathrm{RFD}+\mathrm{Pm} \cdot \mathrm{R} 10$ & 75.46 & 123.7 & 3.58 & 1.99 & 97.05 & 99.53 \\
\hline $\mathrm{T}_{12}: 0.5 \mathrm{RFD}$ & 70.42 & 117.4 & 3.54 & 1.94 & 92.28 & 101.90 \\
\hline $\mathrm{T}_{13}: 0.0 \mathrm{RFD}+\mathrm{Pm} . \mathrm{Th} 7.5$ & 71.49 & 116.9 & 3.42 & 1.99 & 96.62 & 93.07 \\
\hline $\mathrm{T}_{14}: 0.0 \mathrm{RFD}+\mathrm{Pm} . \mathrm{Tv} 7.5$ & 69.77 & 121.6 & 3.48 & 1.97 & 85.80 & 85.54 \\
\hline $\mathrm{T}_{15}: 0.0 \mathrm{RFD}+\mathrm{Pm} \cdot \mathrm{R} 10$ & 68.05 & 114.0 & 3.29 & 1.91 & 85.80 & 72.58 \\
\hline $\mathrm{T}_{16}: 0.0 \mathrm{RFD}+\mathrm{Pm} .0 .0$ & 70.76 & 102.9 & 3.34 & 1.80 & 83.13 & 59.06 \\
\hline LSD $(P=0.05)$ & 13.85 & 14.99 & 0.28 & 0.20 & NS & 10.81 \\
\hline
\end{tabular}

Notes: RFD = Recommended Fertilizer dose for sugarcane (150-50-90-34-3.5 NPKSZn kg ha ${ }^{-1}$ ); Pm.Th7.5 = Enriched Pressmud by Trichoderma harzianum $7.5 \mathrm{t} \mathrm{ha}^{-1}$; Pm.Tv7.5= Enriched Pressmud by Trichoderma viride $7.5 \mathrm{tha}^{-1} ;$ Pm.R10 = Raw Pressmud $10 \mathrm{tha}^{-1}$. 
Table 4. Effect of different treatments on total chlorophyll content, dry matter and leaf area index

\begin{tabular}{|c|c|c|c|}
\hline Treatment & $\begin{array}{c}\text { Total chlorophyll } \\
\text { ( mg/g fresh } \\
\text { weight })\end{array}$ & $\begin{array}{l}\text { Total Dry matter } \\
\text { (kg/square meter) }\end{array}$ & Leaf area index \\
\hline $\mathrm{T}_{1}: \mathrm{RFD}+\mathrm{Pm} . \mathrm{Th} 7.5$ & 1.95 & 2.91 & 4.21 \\
\hline $\mathrm{T}_{2}: \mathrm{RFD}+$ Pm.Tv7.5 & 2.58 & 3.41 & 5.007 \\
\hline $\mathrm{T}_{3}: \mathrm{RFD}+\mathrm{Pm} \cdot \mathrm{R} 10$ & 2.53 & 3.00 & 4.00 \\
\hline $\mathrm{T}_{4}: \mathrm{RFD}$ & 2.06 & 3.23 & 4.53 \\
\hline $\mathrm{T}_{5}: 0.75 \mathrm{RFD}+$ Pm.Th7.5 & 1.66 & 2.93 & 4.48 \\
\hline $\mathrm{T}_{6}: 0.75 \mathrm{RFD}+\mathrm{Pm} . \mathrm{Tv} 7.5$ & 1.900 & 3.32 & 5.00 \\
\hline $\mathrm{T}_{7}: 0.75 \mathrm{RFD}+\mathrm{Pm} \cdot \mathrm{R} 10$ & 1.83 & 3.71 & 5.28 \\
\hline $\mathrm{T}_{8}: 0.75 \mathrm{RFD}$ & 2.24 & 2.88 & 3.80 \\
\hline $\mathrm{T}_{9}: 0.5 \mathrm{RFD}+\mathrm{Pm} . \mathrm{Th} 7.5$ & 2.06 & 2.72 & 4.17 \\
\hline $\mathrm{T}_{10}: 0.5 \mathrm{RFD}+\mathrm{Pm} . \mathrm{Tv} 7.5$ & 2.13 & 3.22 & 4.18 \\
\hline $\mathrm{T}_{11}: 0.5 \mathrm{RFD}+\mathrm{Pm} \cdot \mathrm{R} 10$ & 1.74 & 3.11 & 4.45 \\
\hline $\mathrm{T}_{12}: 0.5 \mathrm{RFD}$ & 2.20 & 2.72 & 3.82 \\
\hline $\mathrm{T}_{13}: 0.0 \mathrm{RFD}+$ Pm.Th7.5 & 2.36 & 2.59 & 4.10 \\
\hline $\mathrm{T}_{14}: 0.0 \mathrm{RFD}+$ Pm.Tv7.5 & 2.06 & 2.23 & 3.55 \\
\hline $\mathrm{T}_{15}: 0.0 \mathrm{RFD}+\mathrm{Pm} \cdot \mathrm{R} 10$ & 2.42 & 2.50 & 4.03 \\
\hline $\mathrm{T}_{16}: 0.0 \mathrm{RFD}+\mathrm{Pm} .0 .0$ & 1.91 & 1.94 & 2.89 \\
\hline $\operatorname{LSD}(P=0.05)$ & 0.59 & 0.87 & 1.32 \\
\hline
\end{tabular}

Notes: RFD = Recommended Fertilizer dose for sugarcane (150-50-90-34-3.5 NPKSZn kg ha ${ }^{-1}$ ); Pm.Th7.5 = Enriched Pressmud by Trichoderma harzianum $7.5 \mathrm{t} \mathrm{ha}^{-1}$; Pm.Tv7.5= Enriched Pressmud by Trichoderma viride $7.5 \mathrm{t} \mathrm{ha}^{-1}$; Pm.R10 = Raw Pressmud $10 \mathrm{t} \mathrm{ha}^{-1}$. 
Table 5. Nutrient contents of sugarcane leaves at 150 days after plantation as affected by enriched pressmud

\begin{tabular}{|c|c|c|c|c|c|}
\hline Treatments & $\begin{array}{l}\mathrm{N} \\
(\%)\end{array}$ & $\begin{array}{c}\mathrm{P} \\
(\%)\end{array}$ & $\begin{array}{l}\mathrm{K} \\
(\%)\end{array}$ & $\begin{array}{c}\mathrm{S} \\
(\%)\end{array}$ & $\begin{array}{l}\mathrm{Zn} \\
(\%)\end{array}$ \\
\hline $\mathrm{T}_{1}: \mathrm{RFD}+\mathrm{Pm} . \mathrm{Th} 7.5$ & 1.26 & 0.13 & 1.18 & 0.133 & 16.0 \\
\hline $\mathrm{T}_{2}: \mathrm{RFD}+\mathrm{Pm} \cdot \mathrm{Tv} 7.5$ & 1.47 & 0.13 & 1.24 & 0.160 & 16.0 \\
\hline $\mathrm{T}_{3}: \mathrm{RFD}+\mathrm{Pm} \cdot \mathrm{R} 10$ & 1.09 & 0.13 & 1.24 & 0.160 & 19.0 \\
\hline $\mathrm{T}_{4}: \mathrm{RFD}$ & 1.32 & 0.13 & 1.18 & 0.140 & 19.0 \\
\hline $\mathrm{T}_{5}: 0.75 \mathrm{RFD}+\mathrm{Pm} . \mathrm{Th} 7.5$ & 1.29 & 0.11 & 1.20 & 0.170 & 20.0 \\
\hline $\mathrm{T}_{6}: 0.75 \mathrm{RFD}+$ Pm.Tv7.5 & 1.54 & 0.09 & 1.16 & 0.170 & 24.0 \\
\hline $\mathrm{T}_{7}: 0.75 \mathrm{RFD}+\mathrm{Pm} . \mathrm{R} 10$ & 1.15 & 0.12 & 1.20 & 0.174 & 24.0 \\
\hline $\mathrm{T}_{8}: 0.75 \mathrm{RFD}$ & 1.21 & 0.15 & 1.10 & 0.160 & 24.0 \\
\hline $\mathrm{T}_{9}: 0.5 \mathrm{RFD}+\mathrm{Pm} . \mathrm{Th} 7.5$ & 1.12 & 0.09 & 1.15 & 0.150 & 19.0 \\
\hline $\mathrm{T}_{10}: 0.5 \mathrm{RFD}+$ Pm.Tv7.5 & 1.21 & 0.11 & 1.22 & 0.160 & 18.0 \\
\hline $\mathrm{T}_{11}: 0.5 \mathrm{RFD}+$ Pm.R10 & 1.01 & 0.10 & 1.21 & 0.170 & 18.0 \\
\hline $\mathrm{T}_{12}: 0.5 \mathrm{RFD}$ & 1.09 & 0.11 & 0.17 & 0.170 & 27.0 \\
\hline $\mathrm{T}_{13}: 0.0 \mathrm{RFD}+\mathrm{Pm} . \mathrm{Th} 7.5$ & 1.12 & 0.11 & 1.11 & 0.160 & 24.0 \\
\hline $\mathrm{T}_{14}: 0.0 \mathrm{RFD}+$ Pm.Tv7.5 & 1.34 & 0.09 & 1.09 & 0.170 & 21.0 \\
\hline $\mathrm{T}_{15}: 0.0 \mathrm{RFD}+\mathrm{Pm} . \mathrm{R} 10$ & 1.18 & 0.11 & 1.12 & 0.170 & 18.0 \\
\hline $\mathrm{T}_{16}: 0.0 \mathrm{RFD}+\mathrm{Pm} .0 .0$ & 1.29 & 0.12 & 1.11 & 0.130 & 18.0 \\
\hline $\operatorname{LSD}(P=0.05)$ & 0.053 & 0.053 & 0.0053 & 0.0053 & 3.746 \\
\hline
\end{tabular}

Notes: RFD = Recommended Fertilizer dose for sugarcane (150-50-90-34-3.5 NPKSZn kg ha ${ }^{-1}$ ); Pm.Th7.5 = Enriched Pressmud by Trichoderma harzianum $7.5 \mathrm{t} \mathrm{ha}^{-1}$; Pm.Tv7.5= Enriched Pressmud by Trichoderma viride $7.5 \mathrm{t} \mathrm{ha}^{-1} ; \mathrm{Pm} . \mathrm{R} 10=$ Raw Pressmud $10 \mathrm{t} \mathrm{ha}^{-1}$ 
Table 6. Status of initial and post harvest soil affected by enriched pressmud treatments for sugarcane production

\begin{tabular}{|c|c|c|c|c|c|c|c|}
\hline \multirow[t]{2}{*}{ Treatment } & \multicolumn{7}{|c|}{ Analytical value } \\
\hline & $\mathrm{pH}$ & $\begin{array}{c}\text { Organic C } \\
(\%)\end{array}$ & $\begin{array}{c}\text { Total N } \\
(\%)\end{array}$ & $\begin{array}{c}\text { Available } \mathrm{P} \\
\left(\mu \mathrm{g}^{-1}\right)\end{array}$ & $\begin{array}{l}\text { Exchangeable } \mathrm{K} \\
\text { (meq /100g soil) }\end{array}$ & $\begin{array}{c}\text { Available } S \\
\left(\mu \mathrm{g}^{-1}\right)\end{array}$ & $\begin{array}{l}\text { Available } \\
\mathrm{Zn}\left(\mu \mathrm{g}^{-1}\right)\end{array}$ \\
\hline Initial soil & 7.62 & 0.46 & 0.06 & 15.0 & 0.18 & 24.0 & 0.64 \\
\hline \multicolumn{8}{|c|}{ Post harvest soil } \\
\hline $\mathrm{T}_{1}: \mathrm{RFD}+\mathrm{Pm} . \mathrm{Th} 7.5$ & 7.6 & 0.78 & 0.091 & 20.0 & 0.20 & 20.0 & 0.61 \\
\hline $\mathrm{T}_{2}: \mathrm{RFD}+\mathrm{Pm} . \mathrm{Tv} 7.5$ & 7.33 & 0.82 & 0.075 & 25.0 & 0.17 & 33.0 & 0.62 \\
\hline $\mathrm{T}_{3}: \mathrm{RFD}+\mathrm{Pm} \cdot \mathrm{R} 10$ & 7.3 & 0.82 & 0.09 & 21.0 & 0.18 & 52.0 & 0.67 \\
\hline $\mathrm{T}_{4}: \mathrm{RFD}$ & 7.4 & 0.76 & 0.081 & 16.0 & 0.21 & 23.0 & 0.58 \\
\hline $\mathrm{T}_{5}: 0.75 \mathrm{RFD}+\mathrm{Pm} . \mathrm{Th} 7.5$ & 7.7 & 0.80 & 0.081 & 23.0 & 0.21 & 23.0 & 0.78 \\
\hline $\mathrm{T}_{6}: 0.75 \mathrm{RFD}+$ Pm.Tv7.5 & 7.44 & 0.93 & 0.081 & 16.0 & 0.21 & 14.0 & 0.50 \\
\hline $\mathrm{T}_{7}: 0.75 \mathrm{RFD}+\mathrm{Pm} \cdot \mathrm{R} 10$ & 7.58 & 0.78 & 0.090 & 17.0 & 0.20 & 21.0 & 0.57 \\
\hline $\mathrm{T}_{8}: 0.75 \mathrm{RFD}$ & 7.53 & 0.47 & 0.070 & 18.0 & 0.20 & 12.0 & 0.50 \\
\hline $\mathrm{T}_{9}: 0.5 \mathrm{RFD}+\mathrm{Pm} . \mathrm{Th} 7.5$ & 7.54 & 0.65 & 0.090 & 16.0 & 0.18 & 29.0 & 0.81 \\
\hline $\mathrm{T}_{10}: 0.5 \mathrm{RFD}+\mathrm{Pm} . \mathrm{Tv} 7.5$ & 7.56 & 0.67 & 0.075 & 16.0 & 0.20 & 23.0 & 0.68 \\
\hline $\mathrm{T}_{11}: 0.5 \mathrm{RFD}+$ Pm.R10 & 7.62 & 0.80 & 0.080 & 19.0 & 0.18 & 21.0 & 0.95 \\
\hline $\mathrm{T}_{12}: 0.5 \mathrm{RFD}$ & 7.66 & 0.78 & 0.077 & 11.0 & 0.17 & 17.0 & 0.54 \\
\hline $\mathrm{T}_{13}: 0.0 \mathrm{RFD}+\mathrm{Pm} . \mathrm{Th} 7.5$ & 7.62 & 0.44 & 0.060 & 10.0 & 0.18 & 14.0 & 0.56 \\
\hline $\mathrm{T}_{14}: 0.0 \mathrm{RFD}+\mathrm{Pm} . \mathrm{Tv} 7.5$ & 7.64 & 0.42 & 0.070 & 9.0 & 0.18 & 13.0 & 0.55 \\
\hline $\mathrm{T}_{15}: 0.0 \mathrm{RFD}+\mathrm{Pm} . \mathrm{R} 10$ & 7.66 & 0.42 & 0.060 & 9.0 & 0.18 & 18.0 & 0.58 \\
\hline $\mathrm{T}_{16}: 0.0 \mathrm{RFD}+\mathrm{Pm} .0 .0$ & 7.64 & 0.45 & 0.064 & 9.0 & 0.17 & 12.0 & 0.56 \\
\hline $\operatorname{LSD}(P=0.05)$ & 0.053 & 0.053 & 0.0053 & 3.679 & 0.0053 & 3.575 & 0.053 \\
\hline
\end{tabular}

Notes: RFD = Recommended Fertilizer dose for sugarcane (150-50-90-34-3.5 NPKSZn kg ha ${ }^{-1}$ ); Pm.Th7.5 = Enriched Pressmud by Trichoderma harzianum $7.5 \mathrm{t} \mathrm{ha}^{-1}$; Pm.Tv7.5= Enriched Pressmud by Trichoderma viride $7.5 \mathrm{t} \mathrm{ha}^{-1} ; \mathrm{Pm} . \mathrm{R} 10=$ Raw Pressmud $10 \mathrm{t} \mathrm{ha}^{-1}$ 